\title{
Effects of aspect and altitude on carbon cycling processes in a temperate mountain forest catchment
}

\author{
Johannes Kobler (D) Bernhard Zehetgruber - Thomas Dirnböck • \\ Robert Jandl $\cdot$ Michael Mirtl $\cdot$ Andreas Schindlbacher
}

Received: 18 July 2018/ Accepted: 7 January 2019/Published online: 22 January 2019

(C) The Author(s) 2019

\begin{abstract}
Context Varying altitudes and aspects within small distances are typically found in mountainous areas. Such a complex topography complicates the accurate quantification of forest $\mathrm{C}$ dynamics at larger scales.

Objectives We determined the effects of altitude and aspect on forest $\mathrm{C}$ cycling in a typical, mountainous catchment in the Northern Limestone Alps.

Methods Forest $\mathrm{C}$ pools and fluxes were measured along two altitudinal gradients (650-900 $\mathrm{m}$ a.s.1.) at south-west (SW) and north-east (NE) facing slopes. Net ecosystem production (NEP) was estimated using a biometric approach combining field measurements of aboveground biomass and soil $\mathrm{CO}_{2}$ efflux (SR) with allometric functions, root:shoot ratios and empirical SR modeling.
\end{abstract}

Electronic supplementary material The online version of this article (https://doi.org/10.1007/s10980-019-00769-z) contains supplementary material, which is available to authorized users.

J. Kobler $(\bowtie) \cdot$ B. Zehetgruber · T. Dirnböck · M. Mirtl Department for Ecosystem Research and Environmental Information Management, Environment Agency Austria, Spittelauer Lände 5, 1090 Vienna, Austria

e-mail: johannes.kobler@umweltbundesamt.at

R. Jandl · A. Schindlbacher

Department of Forest Ecology and Soils, Federal Research and Training Centre for Forests, Natural Hazards and Landscape - BFW, Seckendorff-Gudent Weg 8, 1131 Vienna, Austria
Results NEP was higher at the SW facing slope $\left(6.60 \pm 3.01 \mathrm{t} \mathrm{C} \mathrm{ha}^{-1}\right.$ year $\left.^{-1}\right)$, when compared to the NE facing slope $\left(4.36 \pm 2.61 \mathrm{t} \mathrm{C} \mathrm{ha}^{-1}\right.$ year $\left.^{-1}\right)$. SR was higher at the SW facing slope too, balancing out any difference in NEP between aspects (NE: $1.30 \pm 3.23 \mathrm{t} \mathrm{C} \mathrm{ha}^{-1}$ year $^{-1}$, SW: $1.65 \pm 3.34 \mathrm{t} \mathrm{C}^{-}$ $\mathrm{ha}^{-1}$ year $^{-1}$ ). Soil organic $\mathrm{C}$ stocks significantly decreased with altitude. Forest NPP and NEP did not show clear altitudinal trends within the catchment.

Conclusions Under current climate conditions, altitude and aspect adversely affect $\mathrm{C}$ sequestering and releasing processes, resulting in a relatively uniform forest NEP in the catchment. Hence, including detailed climatic and soil conditions, which are driven by altitude and aspect, will unlikely improve forest NEP estimates at the scale of the studied catchment. In a future climate, however, shifts in temperature and precipitation may disproportionally affect forest $\mathrm{C}$ cycling at the southward slopes through increased water limitation.

Keywords Mountain forest $\mathrm{C}$ cycle $\cdot$ Soil $\mathrm{CO}_{2}$ efflux $\cdot$ Net primary production $\cdot$ Net ecosystem production · Aspect · Altitude $\cdot$ LTER Zöbelboden

\section{Introduction}

In complex mountain terrains, the topography, renders steep gradients in site parameters within small 
distances, thereby promoting gravity-related erosion processes (Konz et al. 2010), creating site-specific (micro-)climatic conditions (Beniston 2005) and developing diverse soil (Häring et al. 2012) and plant landscapes (Fischer et al. 2014). Together, this results in particularly small-scaled and intermingled spatial ecological units, each characterized by a specific set of climatic, physical, chemical and biotic factors (Hansen et al. 2000; Swetnam et al. 2017). Beside triggering spatial variation (Hansen et al. 2000; Thompson and Kolka 2005; Riveros-Iregui and McGlynn 2009; Taylor et al. 2015; Swetnam et al. 2017), these factors also govern variation in the intraannual dynamics of carbon (C) fluxes in the forest landscapes (Kang et al. 2003; Riveros-Iregui et al. 2012; Stielstra et al. 2015). Moreover, the number of drivers may change from the plot to the landscape scale (Kang et al. 2003; Martin and Bolstad 2009; Kelsey et al. 2012).

Due to a longer growing season, a general increase in net primary production (NPP) as well as soil $\mathrm{CO}_{2}$ efflux (SR) can be expected with decreasing forest altitude (Hansen et al. 2000; Rodeghiero and Cescatti 2005; Swetnam et al. 2017). On the other hand, forest soil organic C (SOC) stocks typically increase with altitude due to slow soil organic matter decomposition at the colder higher elevation sites (Schindlbacher et al. 2010; Tashi et al. 2016).

Aspect determines the amount of solar radiation input and thereby affects plant photosynthesis, plant transpiration and site microclimate (Agren and Andersson 2012). While higher radiation inputs increase photosynthetic $\mathrm{C}$ uptake by trees, radiative warming simultaneously increases soil evaporation as well as transpiration rates of the forest vegetation. On shallow soils with low water holding capacity (Lévesque et al. 2013; Kirchen et al. 2017; Rehschuh et al. 2017), increased plant water uptake can lead to water shortage at warmer south facing slopes, while water supply may remain sufficient at more northward oriented slopes at the same time. However, studies disentangling the effect of aspect on forest $\mathrm{C}$ dynamics in forested mountain terrain are rare (Fekedulegn et al. 2003; Smith et al. 2016).

Our study aimed at identifying spatio-temporal patterns of forest $\mathrm{C}$ cycling within the mountainous catchment of the Long-Term Ecosystem Research (LTER) site Zöbelboden in the Northern Limestone Alps, Austria. We aimed at assessing if aspect and/or altitude significantly affected $\mathrm{C}$ sequestration within the region-typical (forested; steep slopes; altitude $\sim 500-1000 \mathrm{~m}$ ) side valley. We used an existing set of forest and soil inventory data, combined with complementary C-flux measurements, such as SR, and forest floor biomass production to estimate forest NPP and net ecosystem production (NEP) along altitudinaltransects of two opposing north-east (NE) and southwest (SW) facing slopes. We hypothesized that NPP and SR generally decreased with altitude due to a shorter vegetation period and that SOC stocks increased with altitude due to slower SOC decomposition at higher and colder sites. Since shallow and stony soils with low soil water holding capacity (SWHC) prevail in the Northern Limestone Alps, we expected water availability being one of the mayor aspect related parameters affecting forest $\mathrm{C}$ cycling. We hypothesized that the SW facing slope experienced frequent water stress which led to lower $\mathrm{C}$ sequestration in biomass (NPP), resulting in overall lower forest NEP at the SW facing slope.

\section{Materials and methods}

\section{Catchment description}

The study was conducted at the LTER site Zöbelboden (N47 $50^{\prime} 30^{\prime \prime}, \quad \mathrm{E} 14^{\circ} 26^{\prime} 30^{\prime \prime}$ ) (https://deims.org/ 8eda49e9-1f4e-4f3e-b58e-e0bb25dc32a6) located in the National Park Kalkalpen, Northern Limestone Alps, Austria. The parent material is dolomite and limestone. The climate is cool humid with maximum precipitation in summer (mean annual temperature and precipitation 1996-2011 were $7.8{ }^{\circ} \mathrm{C}$ and $1645 \mathrm{~mm}$, respectively). The northern part of the site, the so called Zöbelgraben catchment ( $\sim 45$ ha) served for the current study. The catchment is characterized by steep $\left(30-70^{\circ}\right) \mathrm{NE}$ and SW facing slopes. The soil is dominated by shallow Lithic and Rendzic Leptosols (Working Group WRB 2015) with high rock content. The vegetation cover consists primarily of semi-natural mixed forests dominated by European beech (Fagus sylvatica L.) interdispersed by Norway spruce (Picea abies (L.) Karst), silver fir (Abies alba), European larch (Larix decidua Mill.), maple (Acer pseudoplatanus L.) and ash (Fraxinus excelsior). Depending on tree density, the mature forests show proliferating herbaceous ground vegetation (Helm 
et al. 2017). Basic site parameters are presented in Table 1.

\section{Experimental design}

We defined two altitudinal gradients (from approx. 550 to $900 \mathrm{~m}$ a.s.l.; Table 1, Fig. 1) at two opposing (NE and SW-facing) slopes within the catchment in order to assess the effects of altitude and aspect on forest $\mathrm{C}$ cycling. The altitudinal gradients consisted of four sites at each slope. All eight sites are part of the existing LTER framework.

We used data from existing forest (biomass and increment) and soil ( $\mathrm{C}$ and nutrient stocks) inventories collected during the ongoing long-term monitoring of the site, which were complemented by measurements of $\mathrm{C}$ fluxes (SR, ground vegetation productivity) measured during the growing seasons of 2015 and 2016 (Fig. S1). A main focus was on the assessment of aspect and altitudinal effects on net $\mathrm{C}$ uptake by total forest biomass (NPP), and on ecosystem C losses due to respiration (primarily SR), as well as on the overall forest ecosystem productivity (NEP).

Air and soil climate

Five soil temperature loggers $\left(\right.$ iButton $^{\circledR}$ devices, Maxim Integrated, USA) were installed at each of the eight sites in 2010 and data were collected annually, providing three-hourly soil temperature measurements ( $0.05 \mathrm{~m}$ soil depth) for the entire study period (2010-2016) (Fig. S1). Additionally, during SR measurements, soil temperature and soil moisture were measured beside each SR collar (details see below).

Precipitation was measured at a permanent weather station about $600 \mathrm{~m}$ away from the study sites. Due to the short distances, we assumed that precipitation did not vary within the study catchment.

Potential annual global solar radiation $\left(\mathrm{Wh} / \mathrm{m}^{-2}\right)$ was calculated for each site with the Solar Radiation tool (ESRI Spatial Analyst) in ESRI ArcGIS (ESRI 2014) and a digital elevation model (spatial resolution: $30 \times 30 \mathrm{~m}^{2}$ ).

SR measurements and soil C stocks

SR measurement campaigns were conducted monthly during the 2015 and 2016 snow-free seasons at randomly selected ten plots $\left(1 \times 1 \mathrm{~m}^{2}\right)$ within each site (Fig. S1). Each plot was equipped with a permanent soil respiration collar $(0.1 \mathrm{~m}$ diameter, $0.04 \mathrm{~m}$ height, center of the plot). The PVC collars were inserted $0.02 \mathrm{~m}$ into the ground. SR was measured with a portable infrared gas analyzer (EGM-4) and an attached chamber (SRC-1) (PP Systems International Inc., Amesbury, MA, USA). The chamber closure time was $100 \mathrm{~s}$. SR was calculated automatically by fitting a quadratic function to the increasing $\mathrm{CO}_{2}$ headspace concentration. Adjacent

Table 1 Basic site parameters of the eight sites located along two altitudinal gradients at the NE- and SW-facing valley slopes

\begin{tabular}{|c|c|c|c|c|c|c|c|c|}
\hline & NE-facing & & & & SW-facing & & & \\
\hline Altitude (m) & 894 & $791^{\mathrm{a}}$ & 719 & 574 & 866 & $806^{\mathrm{a}}$ & 748 & 600 \\
\hline Slope inclination $\left({ }^{\circ}\right)$ & 35 & 40 & 42 & 40 & 36 & 40 & 36 & 40 \\
\hline Stand density (N ha) & 127 & 448 & 191 & 50 & 255 & 191 & 149 & 414 \\
\hline Basal area $\left(\mathrm{m}^{-2} \mathrm{ha}\right)$ & 19 & 53 & 13 & 1 & 48 & 21 & 14 & 38 \\
\hline Tree species (Braun-Blanquet) & $\begin{array}{l}\text { Fasy (4) } \\
\text { Piab (2b) }\end{array}$ & $\begin{array}{l}\text { Fasy (4) } \\
\text { Fraex (2b) }\end{array}$ & $\begin{array}{l}\text { Fasy (4) } \\
\text { Piab (2a) } \\
\text { Fraex (+) } \\
\text { Acps (+) }\end{array}$ & $\begin{array}{l}\text { Fasyl (4) } \\
\text { Acps. (+) }\end{array}$ & $\begin{array}{l}\text { Acps (4) } \\
\text { Fraex (3) } \\
\text { Fasy (2a) }\end{array}$ & $\begin{array}{l}\text { Fraex (2b) } \\
\text { Fasy (1a) }\end{array}$ & Fasy (3) & Piab (2a) \\
\hline Coverage of herb layer $(\%)$ & 25 & 5 & 45 & 70 & 85 & 75 & 85 & 95 \\
\hline Organic layer thickness $(\mathrm{cm})$ & 2.5 & 4.5 & 3.5 & 7 & 4.5 & 1 & 6 & 3.8 \\
\hline Mineral soil thickness $(\mathrm{cm})$ & 6 & 17 & 11 & 16 & 5 & 5 & 6 & 18 \\
\hline
\end{tabular}

Fasy: Fagus sylvatica L.; Piab: Picea abies (L.) Karst; Fraex: Fraxinus excelsior; Acps: Acer pseudoplatanus L.; Braun-Blanquet coverage in parentheses

${ }^{\text {a }}$ Sites equipped with litter traps 


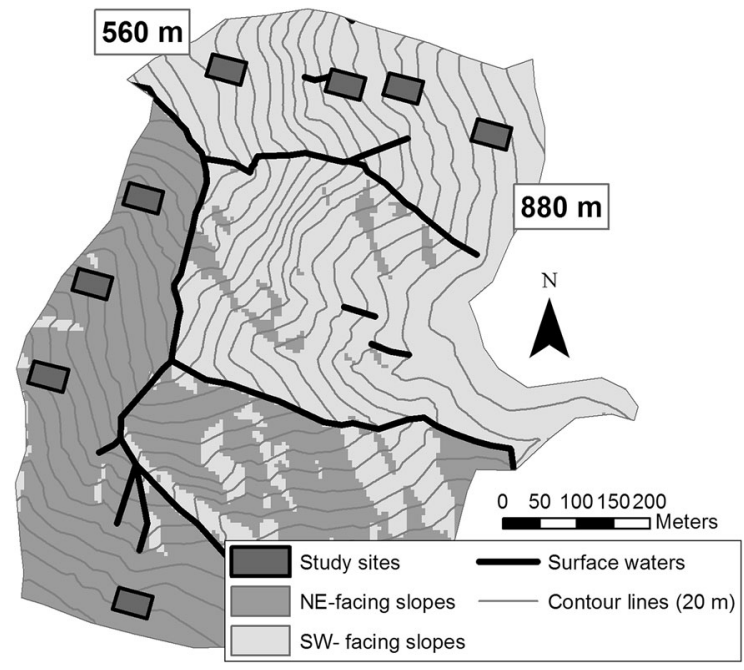

Fig. 1 Areal overview of the eight study sites which were arranged along two altitudinal gradients at two opposing slopes of a narrow steep side valley catchment in the National Park Kalkalpen

to each $\mathrm{CO}_{2}$ collar, soil temperature at $0.05 \mathrm{~m}$ soil depth was recorded with a handheld sensor at the time of SR measurements. Concurrently, a minimum of five mineral soil samples were randomly taken within each site for determination of gravimetric soil water content. Volumetric soil water content (\%) was calculated by multiplying the gravimetric water content with soil bulk density $\left(\mathrm{g} \mathrm{cm}^{-3}\right)$.

We fitted an exponential model with soil temperature as independent variable to the measured (2015 and 2016) SR data (Richardson et al. 2006) (Eq. 1):

$S R=\theta_{1} \times \theta_{2}^{((T-T r e f) \div 10)}$

where $S R$ was the rate of soil $\mathrm{CO}_{2}$ efflux $\left(\mu \mathrm{mol} \mathrm{CO}_{2}\right.$ $\left.\mathrm{m}^{-2} \mathrm{~s}^{-1}\right), T$ the measured soil temperature $\left({ }^{\circ} \mathrm{C}\right), \theta_{1}$ and $\theta_{2}$ model parameters and Tref a fixed reference temperature, in this case $10{ }^{\circ} \mathrm{C}$. Nonlinear (exponential) modeling was performed by means of the $\mathrm{R}$ package minpack.lm (Elzhov et al., 2016). Because soil temperature explained a large proportion of the temporal variation in measured SR (up to 91\%), we used the same model (Eq. 1) to estimate SR during the years 2010 to 2014 . To do so, the model was parameterized for each site using 2015 to 2016 SR and soil temperature data. Subsequently, the obtained model parameters and the daily mean soil temperatures during 2010 to 2014 were used to model daily mean site SR rates between 2010 and 2014. Daily values were summed to generate annual SR sums for the years 2010 until 2016.

Soil bulk density and SOC concentrations were determined from soil samples taken at each of the eight sites during a soil inventory in 2004. Descriptive soil parameters were surveyed at the walls of a soil profile (Table 1). Soil samples were taken within one plot $\left(1 \times 1 \mathrm{~m}^{2}\right)$ (Fig. S1). The forest floor was sampled once in the middle of the plot with a wooden frame $\left(0.3 \times 0.3 \mathrm{~m}^{2}\right)$. Mineral soil was sampled fivefold in the middle of the plot and the midpoints of the surrounding square with a stainless steel soil column cylinder auger $(\mathrm{d}=0.07 \mathrm{~m})$. In the laboratory, roots were separated. The root-free soil samples were dried at $30{ }^{\circ} \mathrm{C}$ until constant weight, sieved to $<2 \mathrm{~mm}$ and weighted. The total content of $\mathrm{C}$ was analyzed by dry combustion (Ströhlein Coulomat 702 and Si 111/6, Ströhlein GmbH \& Co., Germany). The total content of $\mathrm{CaCO}_{3}$ was measured via addition of $\mathrm{HCl}$ and volumetrical determination of the released $\mathrm{CO}_{2}$ (Scheibler) (Normschliff Gerätebau Dr. FriedrichsDr. Matschke GmbH \& Co. KG, Germany). The total content of organic $\mathrm{C}$ was calculated by subtracting the total content of $\mathrm{CaCO}_{3}$ from the total content of $\mathrm{C}$. SOC stocks ( $\mathrm{kg} \mathrm{DW} \mathrm{ha}{ }^{-1}$ ) were calculated for each horizon by multiplying SOC concentration (\%), bulk density $\left(\mathrm{g} \mathrm{m}^{-3}\right)$, and thickness of the horizon (m).

Tree biomass stock

Tree basal area and stem volume was assessed in consecutive inventories in 2010 and 2014 at each of the eight sites $(\mathrm{d}=10 \mathrm{~m})$ (Fig. S1). Prior to the first inventory, each tree was tagged and subsequently its spatial position was recorded. Species, live status, diameter at breast height $(\mathrm{dbh}=1.37 \mathrm{~m})$ and tree height was surveyed. Tree biomass was calculated by species- and tree compartment-specific volume and biomass functions (Zianis et al. 2005; Muukkonen and Mäkipää 2006; Finér et al. 2011) applied to tree metrics surveyed during the inventories. Estimated stem wood volume at field-moist status was converted to biomass at dry weight by multiplying stem volume with species-specific shrinking ratios and speciesspecific average wood densities (ÖNORM B 3012 2003). 


\section{Litter fall}

Six litter traps $(\mathrm{d}=0.68 \mathrm{~m})$ were installed at the midelevation sites of both elevation gradients (Fig. S1). Litter traps were emptied at the end of the growing season in 2015 and 2016. The litter was oven-dried at $37{ }^{\circ} \mathrm{C}$ and weighed. $\mathrm{C}$ content was assumed as $50 \%$ of dry mass. Measurements were primarily carried out to test if the applied allometric biomass functions (see below) provided realistic litterfall estimates under local conditions.

Herbaceous ground vegetation biomass

The biomass of the herbal ground vegetation layer was determined by clipping the herb layer within five random plots $\left(0.5 \times 0.5 \mathrm{~m}^{2}\right)$ at each of the eight study sites in late summer in 2015 and 2016 (Fig. S1). The samples were oven-dried at $60{ }^{\circ} \mathrm{C}$ and weighed. C content was assumed as $50 \%$ of dry mass. The belowground biomass of the herb layer was estimated by multiplying the sampled aboveground biomass with the root:shoot ratio of temperate grasslands (4.224) reported in Mokany et al. (2006). As Mokany et al. (2006) combined live and dead fine roots, the live fine root biomass was estimated by multiplying the overall fine root biomass with an living:dead fine root ratio of 0.6 (Gill et al. 2002).

\section{NPP and NEP}

Mean annual NPP of stems, branches and coarse roots were calculated by dividing the difference of the estimated biomasses in 2010 and 2014 by the respective number of years. Estimated foliage biomass of deciduous trees was considered as annual foliage NPP. The foliage NPP of coniferous tree species was calculated by summing up the mean annual increment of needles with $11.1 \%$ of the standing needle biomass (i.e. needle life span: 8.99 year $^{-1}$ (Withington et al. 2006)). Annual tree fine root turnover (i.e. fine root NPP) was estimated by multiplying standing fine root biomass of Fagus sylvatica with 0.88 year $^{-1}$ and of Picea abies with 0.86 year $^{-1}$ (Brunner et al. 2013). A single turnover rate of 0.64 year $^{-1}$ was adopted for the remaining tree species (Li et al. 2003). Since tree basal area varied among sites, we normalized site NPP and NEP by tree basal area in order to assess altitudinal and aspect-specific effects. C content was estimated by multiplying each biomass number by 0.50 (i.e. assuming $50 \% \mathrm{C}$ content per $\mathrm{t}$ biomass) (Graf Pannatier et al. 2012).

As the study site is characterized by a sustained winter period during which all herbal above ground biomass dies back, the oven-dried foliage biomass of the herb layer was assumed to reflect annual aboveground NPP of the herb layer. The belowground NPP of the herb layer was estimated by multiplying fine root biomass with 0.53 year $^{-1}$ (i.e. turnover rate), which refers to a fine root life span of 1.9 year $^{-1}$. (Gill and Jackson 2000).

Site-specific annual SR sums were calculated as described above (Eq. 1). We multiplied the annual SR sums, which integrate the $\mathrm{CO}_{2}$ respired from plant roots (i.e. autotrophic soil respiration) and the decomposition of dead organic material (i.e. heterotrophic soil respiration), with 0.50 to estimate the amount of heterotrophic soil $\mathrm{CO}_{2}$ efflux (HR) (Hanson et al. 2000; Graf Pannatier et al. 2012). The applied value of 0.50 ( $50 \%$ contribution of HR) is in accordance with results from a trenching experiment in a close similar aged stand (Zehetgruber et al. 2017).

Total ecosystem NPP was calculated by summing up the NPP estimates of stem, branch, coarse roots, foliage/needle, tree fine roots, aboveground biomass of the herb layer and fine root of the herb layer (herbal litter production and NPP were assumed to be similar between 2010-2014 and the years of assessment in 2015-2016). Average annual (2010-2014) NEP was estimated as:

$N E P=N P P-H R$

where NEP is the whole forest ecosystem net ecosystem production, NPP is the sum of tree and ground vegetation NPP (including litter), and $H R$ is the cumulative heterotrophic SR.

\section{Statistical analyses}

We used ordinary least-squares regression (OLS) (Rfunction: $l m$ ) to examine the effect of aspect (AS) and altitude (ALT) on forest $\mathrm{C}$ cycle parameters. We started with the full model (AS + ALT) and used the stepAIC function in the MASS library (Venables and Ripley 2002) with a forward-backward search mode to find the most parsimonious model defined by the lowest AIC (Akaike Information Criterion). Global validation of model assumptions of GLMs was done 
by the gvlma function of the gvlma library (Pena and Slate 2014). Beside AIC, regression coefficients, standard error, statistical significant of the predictors and adjusted $\mathrm{R}^{2}$, and statistical significance of the final models (F-test) were calculated with the $\mathrm{glm}$ function. Standardized regression coefficients were calculated with the lm.beta function of the lm.beta library (Behrendt 2014). We further calculated Pearson correlation coefficients between the defined forest $\mathrm{C}$ cycling parameters and additional site parameters such as soil depth, tree basal areas, and GIS-derived radiation input. If a correlation was statistically significant $(\mathrm{p}<0.05)$, we included the additional parameter in the already fitted OLS and again performed automatically parameter selection by the stepAIC function, thereby testing if the additional parameter improved the final model. Linear regression analyses was used to correlate global radiation, soil temperature, soil moisture, SR, SOC stocks and normalized stem NPP/basal area with altitude. Student's $t$ Test was used to analyze the effect of aspect (i.e. SW vs. NE) on GIS-derived potential global radiation, soil temperature, soil moisture, SR, modeled annual SR sums (mean of 2015-2016 and mean of 2010-2014, respectively), SOC concentrations $(0-0.05 \mathrm{~m})$, SOC stocks, aboveground herb layer NPP, stem NPP, NEP, the remaining $\mathrm{C}$ pools and fluxes. To assess if the drought conditions during summer 2015 had affected one of the measured C cycling parameters, we compared mean May-Sept ( $\sim$ growing season) soil temperature, soil moisture, mean measured SR and modeled total SR of the 2 years $(2015,2016)$ using Paired Student's t-Tests. All data preparation and analyses were done with $\mathrm{R}$ versions 3.3.3-3.4.3 (R Core Team 2017).

\section{Results}

Air and soil climate

Mean soil temperatures (2010-2016) were higher at the SW $\left(9.20 \pm 0.54{ }^{\circ} \mathrm{C}\right)$ compared to the NE facing slope $\left(8.35 \pm 0.67{ }^{\circ} \mathrm{C}\right)$ and declined with altitude (Table 2, Fig. 2). Manually measured soil temperatures during SR campaigns (2015 and 2016 growing seasons) showed a similar trend (SW: $\left.14.11 \pm 0.74{ }^{\circ} \mathrm{C}, \mathrm{NE}: 12.65 \pm 0.88^{\circ} \mathrm{C}\right)$. In 2015 growing season soil temperatures $\left(15.75 \pm 1.38^{\circ} \mathrm{C}\right)$ were significantly higher than in 2016 $\left(14.12 \pm 1.13{ }^{\circ} \mathrm{C}, \mathrm{p}=0.0014\right)$.

The 2015 annual precipitation sum $(1236 \mathrm{~mm}$, LTER Zöbelboden) was the second lowest, after the extreme drought year 2003, over the past 20 years (Fig. 3). The year 2016 (1946 mm) was comparatively wet. Annual precipitation sums between 2010 and 2014 ranged from 1288 to $1715 \mathrm{~mm}$ (mean: $1633 \mathrm{~mm}$ ) showing intermediary values. Mean soil moisture differed significantly $(\mathrm{p}=0.03)$ among the two measurement years $2015(31.2 \pm 4.8 \mathrm{Vol} \%)$ and $2016(34.5 \pm 6.9 \mathrm{Vol} \%)$. Average soil moisture did not show significant differences among aspects (Table 2). During the dry spell in August 2015, soil moisture was explicitly low at all sites, especially at the SW facing slope (Fig. 4). Soil moisture generally increased with altitude within the catchment, but the relationship was only marginally significant ( $p=0.079$, Table 2). At the SW facing slope, soil moisture showed a significant increase with increasing altitude (Fig. 2). Furthermore, soil moisture showed a statistically significant negative correlation with mineral soil depth $(\mathrm{r}=-0.87, \mathrm{p}=0.005)$.

Mean global radiation sums were significantly lower $(p=0.006)$ at the NE exposed slope $\left(1745 \pm 350 \mathrm{Wh} \mathrm{m}^{-2}\right)$ when compared to the $\mathrm{SW}$ exposed slope $\left(2773 \pm 148 \mathrm{Wh} \mathrm{m}^{-2}\right)$. Global radiation sums showed a significant increase with altitude at the SW facing slope, whereas there was no clear relationship with altitude at the $\mathrm{NE}$ facing slope (Fig. 2). At the NE facing slope, the mid-elevation sites showed highest potential radiation input due to their more pronouncedly eastward aspect (Fig. 2).

SR and soil C stocks

Mean measured SR (2015 and 2016) was lower at the NE facing slope $\left(2.39 \pm 0.81 \mu \mathrm{mol} \mathrm{m} \mathrm{m}^{-2} \mathrm{~s}^{-1}\right)$ when compared to the SW facing slope $\left(3.46 \pm 0.60 \mu \mathrm{mol} \mathrm{m} \mathrm{m}^{-2} \mathrm{~s}^{-1}\right)$. The effect of the aspect was, however, only marginally significant $(p=0.079$, Table 2). Over all measurement sites, SR (measured and modeled) did not correlate with altitude (Table 2), but we observed a marginally significant increase in SR with altitude when solely SW facing sites were considered (Fig. 2). SR positively correlated with global radiation input $(r=0.77, p=0.026$, Table 3$)$. When added as additional parameter to the OLS, radiation was automatically selected instead of aspect. 


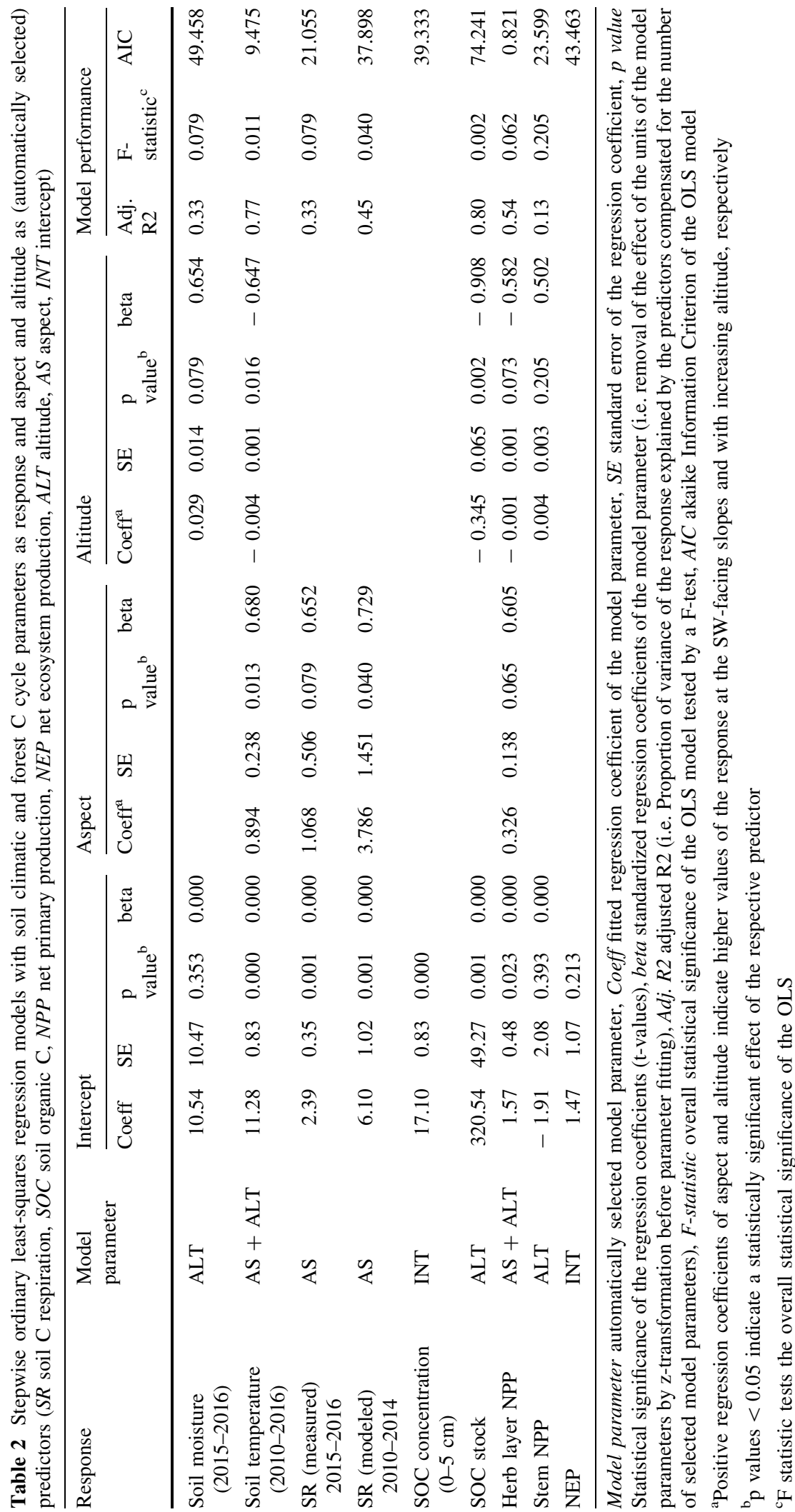




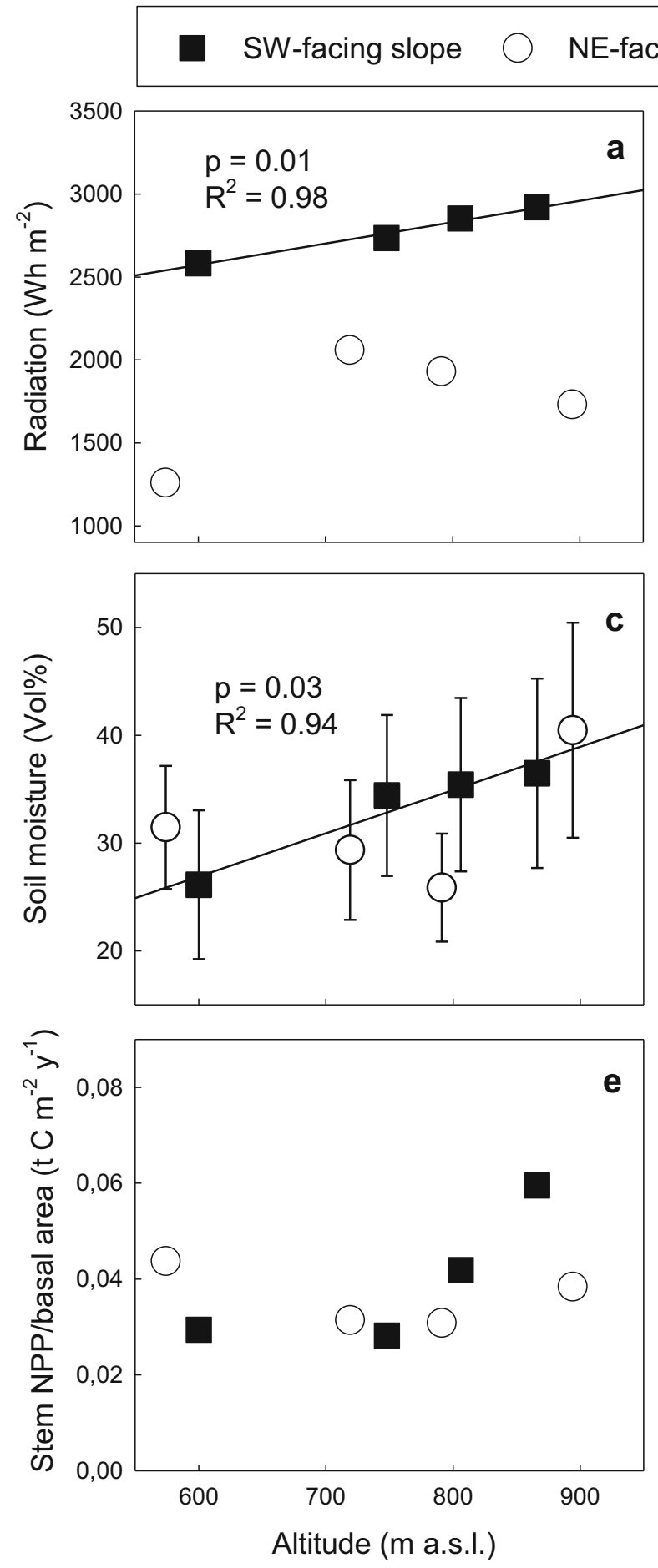

Fig. 2 Effects of site altitude on radiation input (a), soil temperature (b), soil moisture (c), SOC stocks (d), stem NPP normalized by site-specific tree basal area (e), and SR rates (f). Open circles represent sites at the NE-facing slope, full squares
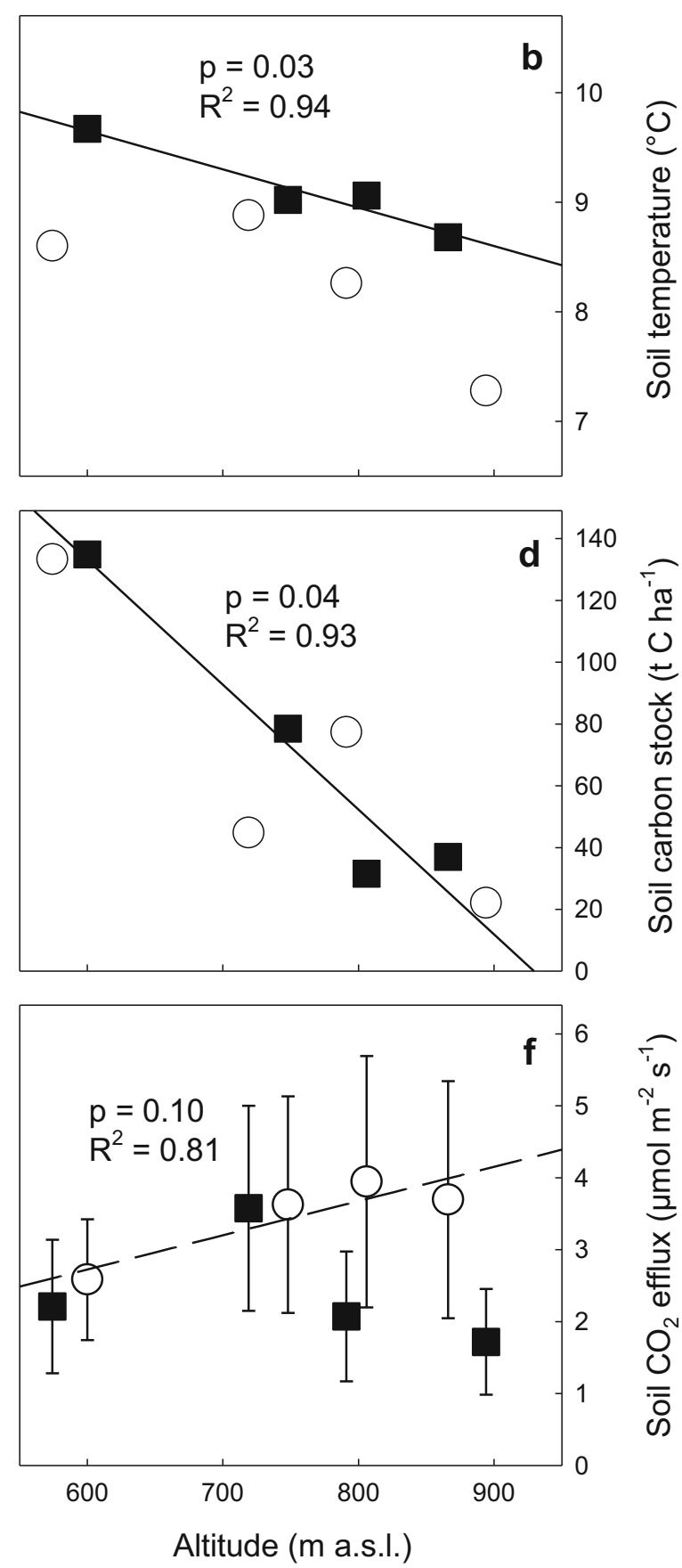

represent sites at the SW-facing slope. Regression lines and the corresponding $\mathrm{R}^{2}$ and $\mathrm{p}$ values are shown for significant (continuous line) and marginally significant (dashed line) relations 


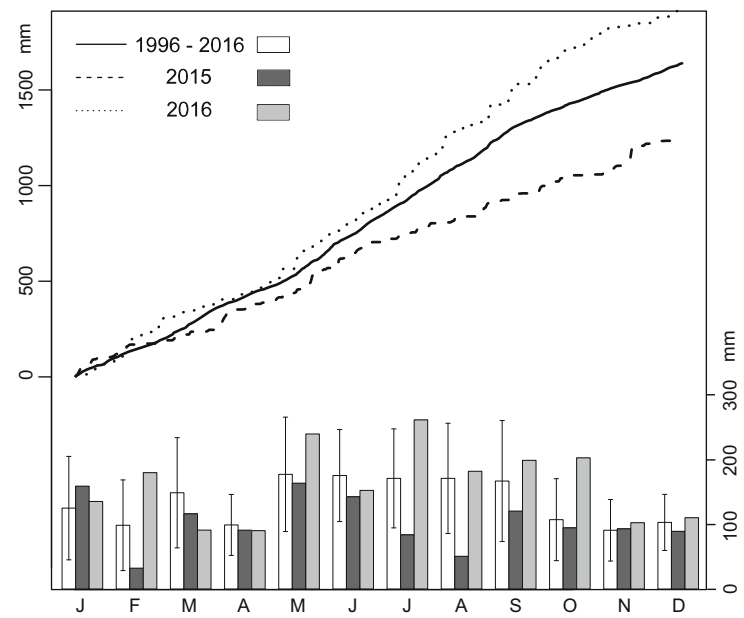

Fig. 3 Cumulative daily precipitation rates of 2015 (dotted line), 2016 (dashed line) and mean value 1996-2016 (bold line) and respective monthly precipitation sums (2015: black bars, 2016: grey bars, 1996-2016: white bars)

The radiation nearly doubled the R2 (OLS(RAD): $\mathrm{R} 2=0.52 ;$ OLS(ALT), R2 $=0.33$ ) and the model got statistically significant $(\mathrm{p}<0.05)$ (Tables 2 and 3). There was no significant correlation between SR and SOC stocks. During the dry conditions in summer 2015, SR dropped by approximately $40 \%$ at the SW facing slope, but only by $\sim 10 \%$ at the NE facing slope (Fig. 4). However, mean measured SR in the catchment was only marginally $(\mathrm{p}=0.053)$ lower in $2015\left(3.25 \pm 1.00 \mu \mathrm{mol} \mathrm{m} \mathrm{m}^{-2} \mathrm{~s}^{-1}\right)$ than in 2016 $\left(3.46 \pm 1.04 \mu \mathrm{mol} \mathrm{m}^{-2} \mathrm{~s}^{-1}\right)$ and there was no significant difference between modeled mean annual catchment SR sums (2015: $8.33 \pm 2.76 \mathrm{t} \mathrm{C} \mathrm{ha}^{-1}$ year $^{-1}$; 2016: $8.21 \pm 2.80 \mathrm{t} \mathrm{C} \mathrm{ha}^{-1}$ year $^{-1}$ ) either.

Modeled mean annual SR sums between 2010 and 2014 (used for forest $\mathrm{C}$ budgets) were significantly $(p=0.04$, Table 4) lower at the NE facing slope $\left(6.11 \pm 2.49 \mathrm{t} \mathrm{C} \mathrm{ha}^{-1}\right.$ year $\left.^{-1}\right)$ when compared to the SW facing slope $\left(9.89 \pm 1.50 \mathrm{t} \mathrm{C} \mathrm{ha}^{-1}\right.$ year $\left.^{-1}\right)$ (Table 4). No statistically significant effects of altitude on modeled SR sums were observed (Table 2). Modeled annual SR sums (2010-2014) correlated positively with GIS-derived global radiation $(r=0.83$, $\mathrm{p}=0.011)$.

SOC concentrations of the uppermost soil horizon $(0-0.05 \mathrm{~m})$ of the $\mathrm{NE}(17.04 \pm 1.42 \%)$ and $\mathrm{SW}$ facing slopes $(17.18 \pm 3.30 \%)$ as well as total SOC stocks of the NE $\left(69.4 \pm 48.3 \mathrm{t} \mathrm{C} \mathrm{ha}^{-1}\right)$ and SW facing slope $\left(70.5 \pm 47.8 \mathrm{t} \mathrm{C} \mathrm{ha}^{-1}\right)$ were similar (Table 5). Aspect and altitude showed no statistically
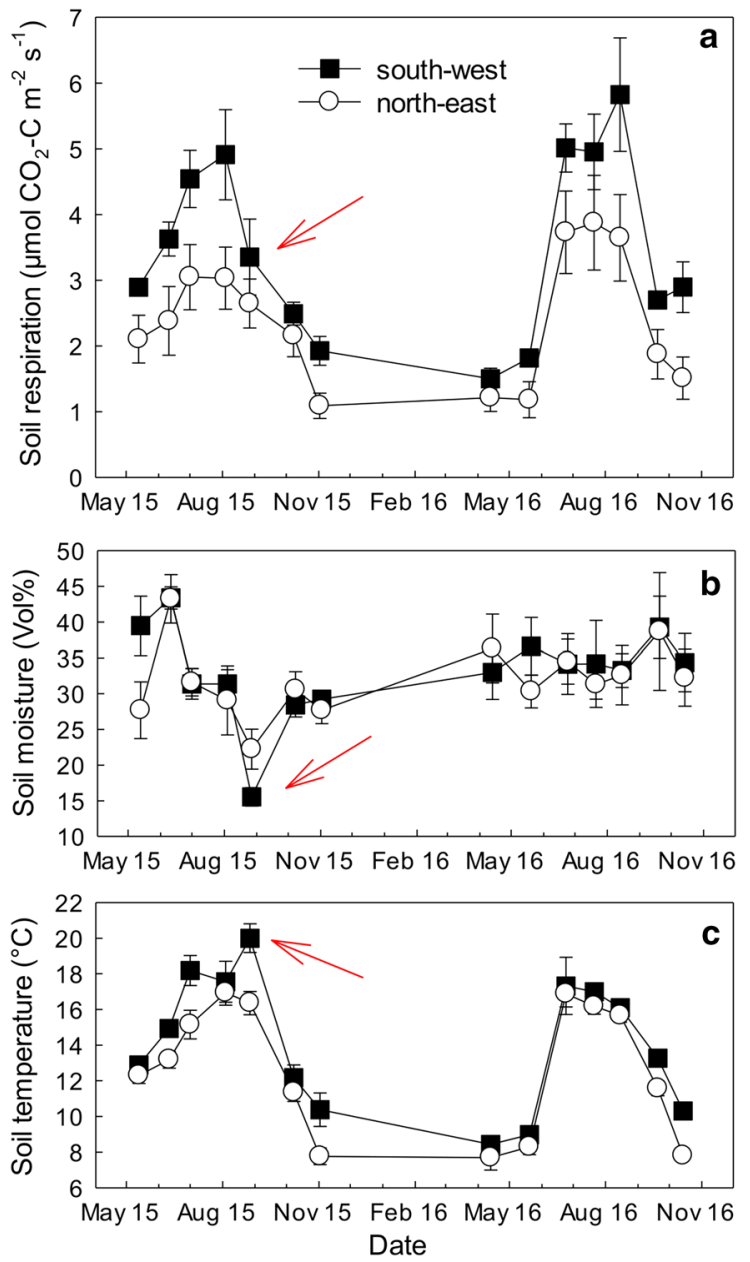

Fig. 4 SR (a), soil moisture (b) and soil temperature at $0.05 \mathrm{~m}$ soil depth (c) during the field campaigns 2015 and 2016. Full squares represent $\mathrm{SW}$-facing sites whereas open circles represent NE-facing sites. Arrows indicate the occurrence of a local soil drought at the SW-facing slope. SR rates dropped sharply during drought, albeit highest soil temperatures

significant effects on SOC concentrations (Table 2). SOC stocks significantly $(\mathrm{p}=0.002)$ increased with decreasing altitude (Table 3, Fig. 2). SOC stocks correlated significantly positively with soil depth $(\mathrm{r}=0.81, \mathrm{p}=0.014)$ and adding the parameter to the OLS(ALT) marginally increased the predictive power of the model (OLS(ALT): R2 $=0.80$; OLS(ALT + SOILDEPTH): R2 = 0.82) $($ Table 3$)$.

Vegetation and ecosystem C pools and fluxes

While the individual forest stands showed strong variability, especially in tree basal area (Table 1), 


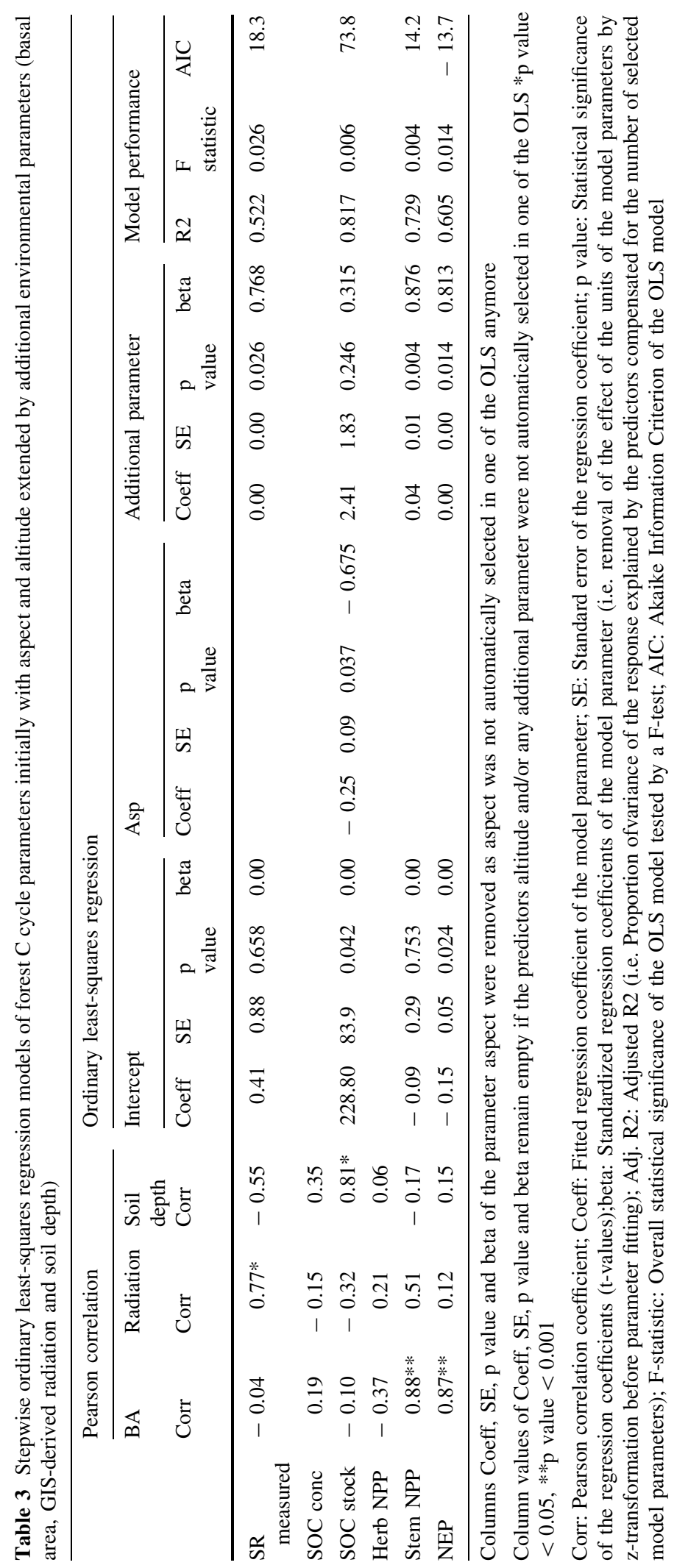


Table 4 Annual NPP of the tree and herb layer, modeled annual total and heterotrophic SR and NEP along the NE and SW facing slopes $(n=4$ sites, mean $\pm \mathrm{SD})$

\begin{tabular}{llr}
\hline & NE facing & SW facing \\
\hline NPP-tree layer & $3.21 \pm 3.11$ & $4.72 \pm 3.38$ \\
Stem & $0.70 \pm 0.68$ & $1.32 \pm 1.08$ \\
Branch & $0.26 \pm 0.24$ & $0.47 \pm 0.57$ \\
Foliage/needle & $1.15 \pm 1.11$ & $1.47 \pm 1.02$ \\
Coarse root & $0.22 \pm 0.15$ & $0.47 \pm 0.30$ \\
Fine root & $0.88 \pm 0.96$ & $1.00 \pm 0.51$ \\
NPP-Herb layer & $1.15 \pm 0.71$ & $1.88 \pm 0.46$ \\
Foliage & $0.49 \pm 0.30$ & $0.80 \pm 0.20$ \\
Fine root & $0.66 \pm 0.40$ & $1.08 \pm 0.26$ \\
NPP-total & $4.36 \pm 2.61$ & $6.60 \pm 3.01$ \\
SR-total & $6.11 \pm 2.49 \mathrm{a}$ & $9.89 \pm 1.50 \mathrm{~b}$ \\
Heterotrophic part $(50 \%)$ & $3.05 \pm 1.24 \mathrm{a}$ & $4.95 \pm 0.75 \mathrm{~b}$ \\
NEP (NPP-Rh) & $1.30 \pm 3.23$ & $1.65 \pm 3.34$ \\
\hline Al paramers ar in & & 0.30 \\
\hline
\end{tabular}

All parameters are in $\mathrm{t} \mathrm{C} \mathrm{ha}^{-1}$ year $^{-1}$. None of the individual parameters varied statistically significant with aspect

Table 5 Average stand structural parameters, above- and belowground $\mathrm{C}$ stocks of tree, herb and soil layers along the two altitudinal gradients at the NE and SW facing valley slopes $(\mathrm{n}=4$ sites, mean $\pm \mathrm{SD})$

\begin{tabular}{|c|c|c|}
\hline & NE facing & SW facing \\
\hline Number of trees & $204 \pm 172$ & $252 \pm 116$ \\
\hline Diameter at breast height $(\mathrm{mm})$ & $315 \pm 105$ & $358 \pm 64$ \\
\hline Tree height $(\mathrm{m})$ & $20 \pm 10$ & $17 \pm 3$ \\
\hline Aboveground tree biomass $\left(\mathrm{t} \mathrm{C}^{-1}\right)$ & $94 \pm 120$ & $88 \pm 61$ \\
\hline Belowground tree biomass $\left(\mathrm{t} \mathrm{C} \mathrm{ha}^{-1}\right)$ & $17 \pm 18$ & $27 \pm 15$ \\
\hline Aboveground tree biomass $\left(\mathrm{t} \mathrm{C} \mathrm{ha}^{-1}\right)$ & $0.5 \pm 0.3$ & $0.8 \pm 0.2$ \\
\hline Belowground tree biomass $\left(\mathrm{t} \mathrm{C} \mathrm{ha}^{-1}\right.$ ) & $1.2 \pm 0.8$ & $2.0 \pm 0.5$ \\
\hline Litter layer (t SOC hal ${ }^{-1}$ ) & $7.9 \pm 3.6$ & $8.7 \pm 6.4$ \\
\hline $\begin{array}{l}\text { Mineral soil layer }(0-0.05 \mathrm{~m})(\mathrm{t} \\
\left.\text { SOC } \mathrm{ha}^{-1}\right)\end{array}$ & $21.2 \pm 5.4$ & $35.7 \pm 17.4$ \\
\hline Mineral soil layer $(0-\max )\left(\mathrm{t} \mathrm{SOC} \mathrm{ha}{ }^{-1}\right)$ & $61.5 \pm 48.0$ & $61.8 \pm 46.9$ \\
\hline
\end{tabular}

None of the individual parameters varied statistically significantly with aspect

average aspect-specific stand structural parameters, such as number of trees, dbh and tree height were similar at the NE and the SW facing slopes (Table 5). Tree layer $\mathrm{C}$ stocks did not show any clear aspectspecific patterns, while herb layer C stocks were higher at the SW facing slope (Table 5). Foliage NPP, as derived from allometric functions, was $2.69 \mathrm{t}$ $\mathrm{C} \mathrm{ha}{ }^{-1}$ year $^{-1}$ for a NE facing site and $0.57 \mathrm{t} \mathrm{C} \mathrm{ha}^{-1}$ year $^{-1}$ for a SW facing site. Annual measured litterfall was in a similar range during 2016 (NE: $2.34 \mathrm{t} \mathrm{C} \mathrm{ha}^{-1}$, SW: $0.87 \mathrm{t} \mathrm{C} \mathrm{ha}^{-1}$ ) indicating, that the allometric functions produced reasonable estimates during average precipitation years.

Aboveground herb layer NPP was marginally significant $(\mathrm{p}=0.065)$ higher at the SW $\left(0.80 \pm 0.20 \mathrm{t} \mathrm{C} \mathrm{ha}^{-1}\right.$ year $\left.^{-1}\right)$ than at the NE $\left(0.49 \pm 0.30 \mathrm{t} \mathrm{C} \mathrm{ha}^{-1}\right.$ year $\left.^{-1}\right)$ facing slope and herb layer NPP showed a marginally significant $(\mathrm{p}=0.073)$ decreasing trend with increasing altitude (Table 3). No significant correlations of herb layer NPP with tree basal area, global radiation and soil depth were found. The share of herb layer NPP to total forest stand NPP was higher at the NE facing slope ( $\sim 40 \%$ ) when compared to the SW facing slope ( $\sim 30 \%)$. Mean catchment aboveground herb layer NPP was similar among the years $2015(0.68 \pm 0.31 \mathrm{t}$ $\mathrm{C} \mathrm{ha}{ }^{-1}$ year $\left.^{-1}\right)$ and $2016\left(0.61 \pm 0.28 \mathrm{t} \mathrm{C} \mathrm{ha}^{-1}\right.$ year $^{-1}$ ). Stem NPP (NE: $0.70 \pm 0.68 \mathrm{t} \mathrm{C} \mathrm{ha}^{-1}$ year $^{-1}$, SW: $1.32 \pm 1.08 \mathrm{t} \mathrm{C} \mathrm{ha}^{-1}$ year $^{-1}$ ) did not show any relationships to altitude or aspect (Tables 2 , 5) but correlated positively with tree basal area $(\mathrm{p}=0.004$, Table 3$)$.

NEP (NE: $1.30 \pm 3.23 \mathrm{t} \mathrm{C} \mathrm{ha}^{-1}$ year $^{-1}$; SW: $1.65 \pm 3.34 \mathrm{t} \mathrm{C} \mathrm{ha}^{-1}$ year $^{-1}$ ) showed no correlation with aspect and altitude, but correlated significantly positive with tree basal area $(\mathrm{p}=0.004$, Tables 2,3 and 5). 


\section{Discussion}

We identified several patterns in forest $\mathrm{C}$ cycling, for which altitude and aspect was important, but our prime hypothesis of lower forest NEP at the warmer and supposedly dryer SW exposed slope, was not confirmed by our data. NEP and soil moisture were not affected by aspect, neither was NEP affected by altitude. Estimated NEP was positive at both aspects, indicating on average $\sim 1.5 \mathrm{t} \mathrm{C}$ sequestration per hectare and year in the years 2010 until 2014. Our NEP estimates at the slope are within the range of forest stand at the neighboring mountain plateau (Kobler et al. 2015; Zehetgruber et al. 2017) and other mountain forests (Kowalski et al. 2004).

In a preceding study in the catchment, Hartl-Meier et al. (2014) found distinctively lower long-term tree increment of spruce and beech at the shallow slope soils with low SWHC, than at the flat mountain plateau with deeper soils and higher SWHC. We therefore hypothesized that stem NPP was lower at SW facing slope due to summertime water-shortage. However, we did not observe distinctive differences between aspects on average soil moisture and stem NPP. During the years 2010-2014, which all received precipitation inputs in the range of long-term averages, the generally low SWHC, combined with aspectspecific microclimate (warmer and higher radiation input at SW), therefore, did not result in the expected water shortage and negative effects on NPP. It has to be noted that NPP in the year 2015, during which a summer drought occurred, was not assessed (forest inventories took place in 2010 and 2014). However, the effects of the drought in August 2015 on NPP, likely was less dramatic as well because $\sim 60 \%$ of the annual sum of monthly tree increments occurs already during spring (May-June) (Kobler unpublished data).

Contrary to our expectations, SR was higher at the SW facing slope, likely owing to two causes. Soil moisture was not limiting the rate of SR for most of the time and SR was strongly correlated to solar radiation input, which was significantly higher at the SW facing slope, indicating higher autotrophic SR at the SW facing slope (Bahn et al. 2009). This is also in accordance with similar soil $\mathrm{C}$ stocks along both aspects, indicating that heterotrophic SR originating from SOM decomposition did not vary with aspect. Only during the dry summer of 2015, soil moisture significantly limited SR for a couple of weeks at the
SW facing sites. The observed decrease in SR typically occurs when soil moisture reaches less than $\sim 20 \mathrm{Vol} \%$, and soil microbes suffer from limited water supply (Knohl et al. 2008; Guidolotti et al. 2013). The 2015 summer drought was, however, too short to strongly affect annual SR sums.

Ground vegetation, ANPP was even slightly higher in the dry year 2015 (SW: $0.84 \mathrm{t} \mathrm{C} \mathrm{ha}^{-1}$ year $^{-1}$, NE: $0.51 \mathrm{t} \mathrm{C} \mathrm{ha}^{-1}$ year $^{-1}$ ) than in the wet year 2016 (SW: $0.76 \mathrm{t} \mathrm{C} \mathrm{ha}^{-1}$ year $^{-1}$, NE: $0.47 \mathrm{t} \mathrm{C} \mathrm{ha}^{-1}$ year $^{-1}$ ) at both valley slopes. Moreover, the (hypothesized water limited) SW facing slopes showed substantially higher ground vegetation ANPP than the NE facing slopes. These results discard water limitation as a significant driver of ground vegetation ANPP (Parton et al. 2012) in our study. The precipitation rates during spring and early summer in 2015 are in the range of the long term mean (Fig. 3) and they may have guaranteed enough ground vegetation growth to mask the negative effect of water limitation in summer. Our study points at the potential significance of ground vegetation NPP for NEP in less densely stocked forests such as those studied, which are rather open, old growth, seminatural mountain forests. At the lowest stocked site in our study, ground vegetation contributed up to $90 \%$ of annual total ecosystem NPP. A study at disturbance sites already showed the significance of fast growing ground vegetation with regard to $C$ sequestration in the catchment (Zehetgruber et al. 2017) and other studies indicate a similar importance of ground vegetation on a larger scale (Nilsson and Wardle 2005; Mayer et al. 2014; Williams et al. 2014). Accordingly, ground vegetation should not be overlooked in $\mathrm{C}$ budgeting.

With regard to altitude, the hypothesized downslope increase in forest NPP was also not supported by our observations. Neither did we find a clear relationship between altitude and NPP (even when normalized for site-specific tree basal area) on the catchment scale, nor at the individual SW or NE facing slopes. Forest NPP is driven by a set of environmental and plant physiological parameters (Agren and Andersson 2012). Whereas, temperature determines the length of the growing season (Jolly et al. 2005), radiation input directly affects photosynthesis rates (Fyllas et al. 2017). Temperature and radiation showed opposite altitudinal trends in the catchment, thereby potentially cancelling out their overall effects on NPP. We cannot rule out that subtle altitudinal patterns in NPP occurred, but due to the strong variations in the 
stocking densities of the different stands, we were not able to detect them. In addition, we studied an altitudinal range of $\sim 350 \mathrm{~m}$, which very likely is not indicative for effects found at larger gradients.

Similar to NPP, SR did not show clear altitudinal patterns. The slightly positive relationship with altitude at the SW facing slope was unexpected, since typical drivers of SR, such as soil temperature (Kang et al. 2003) and SOC stocks (Martin and Bolstad 2009), showed an opposing, i.e. decreasing altitudinal trend. However, at the SW facing slope, radiation input and soil moisture were positively correlated with altitude. Higher radiation input could have caused higher photosynthesis and higher root respiration rates, resulting in increased autotrophic and total SR, respectively, at higher altitude sites, as it was shown in other studies (Tang et al. 2005; Ferréa et al. 2012). The strong correlation of SR with radiation input in the catchment supports this explanation.

Soil C stocks increased downslope, refuting our hypothesis of higher SOC stocks at the colder, higher elevation sites. In comparison to wider mountain valleys with a larger altitudinal and climate gradient, the valley in the study catchment was steep and narrow, thereby emphasizing erosive down-slope transport of litter and soil relative to climate. Deeper soils rich in SOC at steep valley bottoms are wellknown characteristics of mountainous landscapes (Häring et al. 2012). Thus, spatial patterns of SOC stocks within the study catchment were most likely driven by topography, rather than by climatic conditions. Nonetheless, the studied catchment represents a typical landscape form in mountainous regions, so that the observed patterns in SOC stocks are likely to occur more often.

In the Northern Limestone Alps, extended Atlanticborne low pressure zones and orographic uplifting of air masses causing local thunderstorms provide regular and extended precipitation events throughout the seasons. Therefore drought periods are kept comparable short (Wastl and Zängl 2010; Isotta et al. 2014). A modeling study has shown that, in the Northern Limestone Alps, water stress induced reductions in tree growth are likely to occur only during extremely dry years (Weis et al. 2014). In this study, minimum soil depths of $10 \mathrm{~cm}$ generally provided enough water to prevent negative effects on modeled tree transpiration. In another model study, focusing on two beech stands on Rendzic Leptosols at opposing aspects (SW vs. NE), Holst et al. (2010) also found no significantly higher drought stress due to higher evaporation demand on a warmer SW exposed slope. However, the strong response of SR to periodic drought in our study exemplifies that changing future precipitation pattern could affect forest $\mathrm{C}$ cycling. Especially, the sun-exposed SW facing slopes may suffer from increasing water shortage if drought periods become more regular and more extended in the future (Ahrens et al. 2014).

Concerning our $\mathrm{C}$ budgeting approaches, it has to be noted that NEP budgeting base on biometric approaches are prone to considerable uncertainties (Holdaway et al. 2014). Allometric functions and ratios were used to calculate NPP estimates for branches, foliage, and tree roots and corresponding litterfall. Such tree-specific allometric functions are based on general relationships between different tree compartments, stem diameter, and tree height (Zianis et al. 2005; Muukkonen and Mäkipää 2006; Finér et al. 2011), which, however, vary with tree form and forest structure affected by specific site and climate conditions. For instance, water limitation can affect $\mathrm{C}$ allocation within trees (Kirchen et al. 2017) rendering inaccurate root and foliage NPP based on a biometric approach. To check the performance of the allometric foliage functions, we had measured litterfall at two mid-slope sites. The foliage NPP, calculated by allometric functions, was close to our measured litterfall in the year 2016 (average precipitation) at both aspects. Accordingly, in the dry year 2015, litterfall was similar to litterfall, as derived with allometric functions, at the NE facing slope, but higher at the SW facing slope (allometric function: $0.57 \mathrm{t} \mathrm{C}$ ha $^{-1}$, measured: $1.33 \mathrm{t} \mathrm{C} \mathrm{ha}^{-1}$ ). These results indicate that the biometric approach shows weaknesses during years with more extreme climate. Standing fine root C of the herb and the tree layer was validated by comparing allometrically estimated fine root $\mathrm{C}$ mass with soil inventory-based fine root assessments. Measured root biomass corresponded well with those derived from allometric functions (Table S1). A major difficulty in our study area was the variation in stocking densities (tree basal areas) and dbh. Beside the similar, above-average tree age ( $>200$ years) (Hartl-Meier et al. 2014), the different forest stands in the catchment varied in stand density, the diversity of tree species, and the stem diameter distribution. This rather typical structural variation of semi-natural 
forests (Tíscar and Lucas-Borja 2016) had the consequence that relatively open stands were compared with more densely stocked stands. Accordingly, the application of the same allometric functions for differently sized trees could, as well, have imposed potential bias in tree NPP estimates (Keller et al. 2001; Chave et al. 2004). However, this was mostly an issue with regard to altitudinal NPP patterns, since stand density varied primarily with altitude. For the determination of aspect effects, the slope-specific site averages generated a more uniform tree size distribution.

Another source of potential uncertainty in our study is the relatively rough estimation of heterotrophic soil respiration (HR), which was assumed as $50 \%$ of SR. Though the mean annual contribution of HR is around $50 \%$ in forests (Hanson et al. 2000) and previous assessments at the LTER site showed a contribution of HR between $\sim 50$ and $60 \%$ in a mature forest closeby (Kobler et al. 2015; Zehetgruber et al. 2017), we cannot guarantee that the contribution of HR was equal across our aspect and elevation gradients. Actually, our results indicate that radiation input was an important driver of SR. Therefore the contributions of HR to SR are likely not the same at catchment sites with low and high radiation input. However, even if we over or underestimated the HR contribution to SR by $10 \%$, this would not have affected the study outcome regarding NEP (no significant variation of NEP with aspect and altitude within the catchment).

Notwithstanding the identified limitations and uncertainties, we are confident that the applied methods were adequate to answer our prime questions whether aspect or altitude had significantly affected forest $\mathrm{C}$ dynamics in the studied catchment valley. We conclude that though single $\mathrm{C}$-cycling parameters significantly differ with altitude and aspect, the overall $\mathrm{C}$ balances (NEP) of the mature mountain forest stands were not significantly affected by these factors. Hence, including detailed climatic and soil conditions, which are driven by altitude and aspect, will unlikely improve forest NEP estimates at the scale of the study catchment (narrow steep mid-elevation side valley), which represents a typical landscape form of the Northern Limestone Alps.

Acknowledgements The study was funded by the Austrian Climate Research Program (ACRP7 - CentForCSink KR14AC7K11960) and received additional funding from the European Union's Horizon 2020 research and innovation program (Grant Agreement No. 641762, ECOPOTENTIAL) and from the Austrian Academy of Sciences Research Program (Earth System Sciences) (C-ALP, Disturbance Impacts on Forest Carbon Dynamics in the Calcareous Alps). We thank Bogner Manfred und Thomas Lehner for their help in the field surveys.

Open Access This article is distributed under the terms of the Creative Commons Attribution 4.0 International License (http:// creativecommons.org/licenses/by/4.0/), which permits unrestricted use, distribution, and reproduction in any medium, provided you give appropriate credit to the original author(s) and the source, provide a link to the Creative Commons license, and indicate if changes were made.

Funding This study was funded by the Austrian Climate Research Program, the European Union's Horizon 2020 research and innovation program and the Austrian Academy of Sciences Research Program (Earth System Sciences).

\section{References}

Agren GI, Andersson FO (2012) Terrestrial ecosystem ecology. NRC Research Press, Ottawa

Ahrens B, Formayer H, Gobiet A, Heinrich G, Hofstätter M, Matulla C, Prein AF, Truhetz H (2014) Zukünftige Klimaentwicklung. In: (APCC), A.P.o.C.C. (ed) Österreichischer Sachstandsbericht Klimawandel 2014 (AAR14). Verlag der Österreichischen Akademie der Wissenschaften, Wien, pp 301-346

Bahn M, Schmitt M, Siegwolf R, Richter A, Brüggemann N (2009) Does photosynthesis affect grassland soil-respired $\mathrm{CO}_{2}$ and its carbon isotope composition on a diurnal timescale? New Phytol 182:451-460

Behrendt S (2014) 1m.beta: Add Standardized Regression Coefficients to $1 \mathrm{~m}-\mathrm{Objects} \mathrm{R}$ package version 1.5-1. https:// CRAN.R-project.org/package $=1 \mathrm{~m}$.beta

Beniston M (2005) Mountain climates and climatic change: an overview of processes focusing on the European Alps. Pure Appl Geophys 162:1587-1606

Brunner I, Bakker, MR, Björk RG, Hirano Y, Lukac M, Aranda $\mathrm{X}$, Børja I, Eldhuset TD, Helmisaari HS, Jourdan C, Konôpka B, López BC, Miguel Pérez C, Persson H, Ostonen I (2013) Fine-root turnover rates of European forests revisited: an analysis of data from sequential coring and ingrowth cores. Plant Soil 362:357-372

Chave J, Condit R, Aguilar S, Hernandez A, Lao S, Perez R (2004) Error propagation and scaling for tropical forest biomass estimates. Philos Trans R Soc Lond B 359:409

Elzhov, TV, Mullen, KM, Spiess AN, Bolker B (2016) minpack.lm: R Interface to the Levenberg-Marquardt Nonlinear Least-Squares Algorithm Found in MINPACK, Plus Support for Bounds. R package version 1.2-1. https:// CRAN.R-project.org/package $=$ minpack. $1 \mathrm{~m}$

ESRI (2014) ArcGIS Desktop: Release 10.2. Environmental Systems Research Institute, Redlands, CA

Fekedulegn D, Hicks RR, Colbert J (2003) Influence of topographic aspect, precipitation and drought on radial growth 
of four major tree species in an Appalachian watershed. For Ecol Manag 177:409-425

Ferréa C, Zenone T, Comolli R, Seufert G (2012) Estimating heterotrophic and autotrophic soil respiration in a seminatural forest of Lombardy, Italy. Pedobiologia 55:285-294

Finér L, Ohashi M, Noguchi K, Hirano Y (2011) Factors causing variation in fine root biomass in forest ecosystems. For Ecol Manag 261:265-277

Fischer HS, Michler B, Ewald J (2014) Environmental, spatial and structural components in the composition of mountain Forest in the Bavarian Alps. Folia Geobot 49:361-384

Fyllas NM, Bentley LP, Shenkin A, Asner GP, Atkin OK, Díaz S, Enquist BJ, Farfan-Rios W, Gloor E, Guerrieri R (2017) Solar radiation and functional traits explain the decline of forest primary productivity along a tropical elevation gradient. Ecol Lett 20:730-740

Gill RA, Jackson RB (2000) Global patterns of root turnover for terrestrial ecosystems. New Phytol 147:13-31

Gill RA, Kelly RH, Parton WJ, Day KA, Jackson RB, Morgan JA, Scurlock JMO, Tieszen LL, Castle JV, Ojima DS, Zhang XS (2002) Using simple environmental variables to estimate below-ground productivity in grasslands. Glob Ecol Biogeogr 11:79-86

Graf Pannatier E, Dobbertin M, Heim A, Schmitt M, Thimonier A, Waldner P, Frey B (2012) Response of carbon fluxes to the 2003 heat wave and drought in three mature forests in Switzerland. Biogeochemistry 107:295-317

Guidolotti G, Rey A, D'Andrea E, Matteucci G, De Angelis P (2013) Effect of environmental variables and stand structure on ecosystem respiration components in a Mediterranean beech forest. Tree Physiol 33:960-972

Hansen AJ, Rotella JJ, Kraska MPV, Brown D (2000) Spatial patterns of primary productivity in the Greater Yellowstone Ecosystem. Landscape Ecol 15:505-522

Hanson PJ, Edwards NT, Garten CT, Andrews JA (2000) Separating root and soil microbial contributions to soil respiration: a review of methods and observations. Biogeochemistry 48:115-146

Häring T, Dietz E, Osenstetter S, Koschitzki T, Schröder B (2012) Spatial disaggregation of complex soil map units: a decision-tree based approach in Bavarian forest soils. Geoderma 185:37-47

Hartl-Meier C, Zang C, Büntgen U, Esper J, Rothe A, Göttlein A, Dirnböck T, Treydte K (2014) Uniform climate sensitivity in tree-ring stable isotopes across species and sites in a mid-latitude temperate forest. Tree Physiol. https://doi. org/10.1093/treephys/tpu096

Helm N, Essl F, Mirtl M, Dirnböck T (2017) Multiple environmental changes drive forest floor vegetation in a temperate mountain forest. Ecol Evol 7:2155-2168

Holdaway R, McNeill S, Mason NH, Carswell F (2014) Propagating uncertainty in plot-based estimates of forest carbon stock and carbon stock change. Ecosystems 17:627-640

Holst J, Grote R, Offermann C, Ferrio J, Gessler A, Mayer H, Rennenberg H (2010) Water fluxes within beech stands in complex terrain. Int J Biometeorol 54:23-36

Isotta FA, Frei C, Weilguni V, Perčec Tadić M, Lassegues P, Rudolf B, Pavan V, Cacciamani C, Antolini G, Ratto SM (2014) The climate of daily precipitation in the Alps: development and analysis of a high-resolution grid dataset from pan-Alpine rain-gauge data. Int $\mathrm{J}$ Climatol 34:1657-1675

Jolly WM, Dobbertin M, Zimmermann NE, Reichstein M (2005) Divergent vegetation growth responses to the 2003 heat wave in the Swiss Alps. Geophys Res Lett. https://doi. org/10.1029/2005g1023252

Kang S, Doh S, Lee D, Lee D, Jin VL, Kimball JS (2003) Topographic and climatic controls on soil respiration in six temperate mixed-hardwood forest slopes. Korea Glob Change Biol 9:1427-1437

Keller M, Palace M, Hurtt G (2001) Biomass estimation in the Tapajos National Forest, Brazil: examination of sampling and allometric uncertainties. For Ecol Manag 154:371-382

Kelsey KC, Wickland KP, Striegl RG, Neff JC (2012) Variation in soil carbon dioxide efflux at two spatial scales in a topographically complex Boreal forest. Arctic Antarctic Alpine Res 44:457-468

Kirchen G, Calvaruso C, Granier A, Redon P-O, Van der Heijden G, Bréda N, Turpault M-P (2017) Local soil type variability controls the water budget and stand productivity in a beech forest. For Ecol Manag 390:89-103

Knohl A, Søe ARB, Kutsch WL, Göckede M, Buchmann N (2008) Representative estimates of soil and ecosystem respiration in an old beech forest. Plant Soil 302:189-202

Kobler J, Jandl R, Dirnböck T, Mirtl M, Schindlbacher A (2015) Effects of stand patchiness due to windthrow and bark beetle abatement measures on soil $\mathrm{CO}_{2}$ efflux and net ecosystem productivity of a managed temperate mountain forest. Eur J For Res. https://doi.org/10.1007/s10342-0150882-2

Konz N, Baenninger D, Konz M, Nearing M, Alewell C (2010) Process identification of soil erosion in steep mountain regions. Hydrol Earth Syst Sci 14:675-686

Kowalski AS, Loustau D, Berbigier P, Manca G, Tedeschi V, Borghetti M, Valentini R, Kolari P, Berninger F, Rannik Ü (2004) Paired comparisons of carbon exchange between undisturbed and regenerating stands in four managed forests in Europe. Glob Change Biol 10:1707-1723

Lévesque M, Saurer M, Siegwolf R, Eilmann B, Brang P, Bugmann H, Rigling A (2013) Drought response of five conifer species under contrasting water availability suggests high vulnerability of Norway spruce and European larch. Glob Change Biol 19:3184-3199

Li Z, Kurz WA, Apps MJ, Beukema SJ (2003) Belowground biomass dynamics in the Carbon Budget Model of the Canadian Forest Sector: recent improvements and implications for the estimation of NPP and NEP. Can J For Res 33:126-136

Martin JG, Bolstad PV (2009) Variation of soil respiration at three spatial scales: components within measurements, intra-site variation and patterns on the landscape. Soil Biol Biochem 41:530-543

Mayer M, Matthews B, Schindlbacher A, Katzensteiner K (2014) Soil $\mathrm{CO}_{2}$ efflux from mountainous windthrow areas: dynamics over 12 years post-disturbance. Biogeosciences 11:6383-6417

Mokany K, Raison RJ, Prokushkin AS (2006) Critical analysis of root: shoot ratios in terrestrial biomes. Glob Change Biol 12:84-96 
Muukkonen P, Mäkipää R (2006) Biomass equations for European trees: addendum. Silva Fennica. https://doi.org/ 10.14214/sf.475

Nilsson M-C, Wardle DA (2005) Understory vegetation as a forest ecosystem driver: evidence from the northern Swedish boreal forest. Front Ecol Environ 3:421-428

ÖNORM B 3012 (2003) Holzarten - Kennwerte zu den Benennungen und Kurzzeichen der ÖNORM EN 13556 (Wood species-characteristic values to terms and symbols of ÖNORM EN 13556). Austrian Standard, Wien

Parton W, Morgan J, Smith D, Del Grosso S, Prihodko L, LeCain D, Kelly R, Lutz S (2012) Impact of precipitation dynamics on net ecosystem productivity. Glob Change Biol 18:915-927

Pena EAP, Slate EH (2014) gvlma: Global Validation of Linear Models Assumptions. R package version 1.0.0.2. https:// CRAN.R-project.org/package $=$ gvlma

R Core Team (2017) R: A language and environment for statistical computing. R Foundation for Statistical Computing, Vienna, Austria. https:/www.R-project.org/

Rehschuh R, Mette T, Menzel A, Buras A (2017) Soil properties affect the drought susceptibility of Norway spruce. Dendrochronologia 45:81-89

Richardson AD, Braswell BH, Hollinger DY, Burman P, Davidson EA, Evans RS, Flanagan LB, Munger JW, Savage K, Urbanski SP, Wofsy SC (2006) Comparing simple respiration models for eddy flux and dynamic chamber data. Agric For Meteorol 141:219-234

Riveros-Iregui DA, McGlynn BL (2009) Landscape structure control on soil $\mathrm{CO}_{2}$ efflux variability in complex terrain: scaling from point observations to watershed scale fluxes. J Geophys Res. https://doi.org/10.1029/2008jg000885

Riveros-Iregui DA, McGlynn BL, Emanuel RE, Epstein HE (2012) Complex terrain leads to bidirectional responses of soil respiration to inter-annual water availability. Glob Change Biol 18:749-756

Rodeghiero M, Cescatti A (2005) Main determinants of forest soil respiration along an elevation/temperature gradient in the Italian Alps. Glob Change Biol 11:1024-1041

Schindlbacher A, de Gonzalo C, Díaz-Pinés E, Gorría P, Matthews B, Inclán R, Zechmeister-Boltenstern S, Rubio A, Jandl R (2010) Temperature sensitivity of forest soil organic matter decomposition along two elevation gradients. J Geophys Res. https://doi.org/10.1029/ 2009JG001191

Smith LA, Eissenstat DM, Kaye MW (2016) Variability in aboveground carbon driven by slope aspect and curvature in an eastern deciduous forest, USA. Can J For Res 47:149-158

Stielstra CM, Lohse KA, Chorover J, McIntosh JC, BarronGafford GA, Perdrial JN, Litvak M, Barnard HR, Brooks PD (2015) Climatic and landscape influences on soil moisture are primary determinants of soil carbon fluxes in seasonally snow-covered forest ecosystems. Biogeochemistry 123:447-465

Swetnam TL, Brooks PD, Barnard HR, Harpold AA, Gallo EL (2017) Topographically driven differences in energy and water constrain climatic control on forest carbon sequestration Ecosphere 8:e01797

Tang J, Baldocchi DD, Xu L (2005) Tree photosynthesis modulates soil respiration on a diurnal time scale. Glob Change Biol 11:1298-1304

Tashi S, Singh B, Keitel C, Adams M (2016) Soil carbon and nitrogen stocks in forests along an altitudinal gradient in the eastern Himalayas and a meta-analysis of global data. Glob Change Biol 22:2255-2268

Taylor P, Asner G, Dahlin K, Anderson C, Knapp D, Martin R, Mascaro J, Chazdon R, Cole R, Wanek W, Hofhansl F, Malavassi E, Vilchez-Alvarado B, Townsend A (2015) Landscape-scale controls on aboveground forest carbon stocks on the Osa Peninsula, Costa Rica. PLoS ONE 10:e0126748

Thompson JA, Kolka RK (2005) Soil carbon storage estimation in a forested watershed using quantitative soil-landscape modeling. Soil Sci Soc Am J 69:1086-1093

Tíscar PA, Lucas-Borja ME (2016) Structure of old-growth and managed stands and growth of old trees in a Mediterranean Pinus nigra forest in southern Spain. Forestry 89:201-207

Venables WN, Ripley BD (2002) Modern applied statistics with $\mathrm{S}$, 4th edn. Springer, New York. ISBN 0-387-95457-0

Wastl C, Zängl G (2010) Mountain-valley precipitation differences in the northern Alps: an exemplary high-resolution modeling study. Meteorol Atmos Phys 108:29-42

Weis W, Blumenthal B, Göttlein A (2014) Wälder der nördlichen Kalkalpen: Ernährung. Wasser-und Stoffhaushalt LWF aktuell 99:38

Williams CA, Vanderhoof MK, Khomik M, Ghimire B (2014) Post-clearcut dynamics of carbon, water and energy exchanges in a midlatitude temperate, deciduous broadleaf forest environment. Glob Change Biol 20:992-1007

Withington JM, Reich PB, Oleksyn J, Eissenstat DM (2006) Comparisons of structure and life span in roots and leaves among temperate trees. Ecol Monogr 76:381-397

Working Group WRB I (2015) World Reference Base for Soil Resources 2014, update 2015 International soil classification system for naming soils and creating legends for soil maps. World Soil Resources Reports No. 106. FAO, Rome

Zehetgruber B, Kobler J, Dirnböck T, Jandl R, Seidl R, Schindlbacher A (2017) Intensive ground vegetation growth mitigates the carbon loss after forest disturbance. Plant Soil. https://doi.org/10.1007/s11104-017-3384-9

Zianis D, Muukkonen P, Mäkipää R, Mencuccini M (2005) Biomass and stem volume equations for tree species in Europe. Silva Fennica Monogr 4:1-63 